\title{
How to Improve Sustainable Competitive Advantage from the Distributor and the Supplier Networks: Evidence from the Paper-Making Industry in China
}

\author{
Haifeng Wang ${ }^{1}$, Pengfei Han ${ }^{2}$ and Weishu Liu ${ }^{3, *(D)}$ \\ 1 School of Business and Management, Shanghai International Studies University, Shanghai 200083, \\ China; wanghf@shisu.edu.cn \\ 2 School of Accounting, Nanjing University of Finance and Economics, Nanjing 210023, China; \\ pengfeihan@nufe.edu.cn \\ 3 School of Information Management and Engineering, Zhejiang University of Finance and Economics, \\ Hangzhou 310018, China \\ * Correspondence: weishuliu@zufe.edu.cn; Tel.: +86-15900815602
}

Received: 25 May 2018; Accepted: 14 June 2018; Published: 15 June 2018

\begin{abstract}
Confronted with urgent green requirements from customers and government, firms in high pollution and high resource-consuming industries must make changes and adopt green strategies as well as knowledge-management strategies to develop and sell green products to improve sustainable competitive advantage. To study how to leverage social networks to improve sustainable competitive advantage, our article sheds light on the effects of structural holes in the distributor network as well as in the supplier network and explores how mutual trust could moderate the impact of structural holes in both networks. Based on data from 122 matched pairs of suppliers and distributors of a high-pollution and high-resource-consuming industry, the Chinese paper-making industry, our empirical results demonstrate the positive effects of structural holes in the distributor and the supplier networks on the distributor sustainable competitive advantage. In addition, mutual trust could negatively moderate the relationship between structural holes in the distributor network and the distributor sustainable competitive advantage, but would positively moderate the relationship between structural holes in the supplier network and the distributor sustainable competitive advantage.
\end{abstract}

Keywords: sustainable competitive advantage; green strategy; structural holes; distributor; supplier; trust; knowledge management

\section{Introduction}

With rapid economic development in China, high pollution and high resource-consumption are important issues for firms and the government to be confronted with, thus it is imperative for firms to develop and sell green, novel products to satisfy the needs of customers and government, and to improve sustainable competitive advantage. Along with the important impact of sustainable competitive advantage suggested by strategic management research [1-4], we have witnessed a rapid proliferation of sustainable competitive advantage in recent decades $[5,6]$. The motivation to establish and improve sustainable competitive advantage is to discover new customers' needs or opportunities of novel, green products [7]. Thus, firms could experiment with new knowledge, access partners' tacit knowledge, evaluate the intrinsic value of the knowledge from these sources [8], and integrate and transfer knowledge into novel, green products to improve sustainable competitive advantage $[9,10]$.

To improve sustainable competitive advantage, two important characteristics should be considered [7,11]. First, novel knowledge is urgently needed for developing and selling novel, 
green products, which requires wide knowledge sources [12,13]. Second, high risks exist in the procedures of knowledge exchange, and thus firms should build interorganizational trust to overcome opportunistic behaviors $[8,14]$. However, paradoxical phenomena would occur regarding these two characteristics. On the one hand, if two firms' interorganizational trust is low, weak ties can contribute to acquire novel, heterogeneous knowledge more efficiently. However, it is hard to avoid opportunism when confronted with low trust $[15,16]$. On the other hand, when two firms have established deep interorganizational trust, their knowledge would tend to be homogeneous but not novel $[17,18]$.

We argue that the paradox is caused by the unexplored issues in prior research. As social networks are increasingly important sources of superior green performance and sustainable competitive advantage [19-21], firms need to acquire knowledge for developing and selling green products by effectively leveraging social networks [2,22]. However, although the existing studies provide rich insights into social networks [1,2], scholars tend to discuss how the network structure of the focal firm works in an isolated network [1,23]. As firms are often embedded into several types of networks simultaneously $[24,25]$, network members could be involved in different networks. The network structure, providing signals about its knowledge background, would influence the decision of the focal firm to cooperate for developing and selling novel, green products $[24,26]$. In this case, the extent to which the focal firm could acquire novel knowledge from network partners depends on both its own network and the partners' network [27]. In particular, apart from its own network [28], it is necessary for the distributor to pay great attention to the signals suggested by the supplier networks for latent knowledge acquisition [29]. Structural holes, as one of the most important network structure [30], could affect the efficiency of knowledge acquisition [31]. Thus, in this article, we intend to focus on the effects of structural holes in the distributor and supplier external ego network to improve the distributor sustainable competitive advantage.

Further, regarding trust- the key factor contributing to cooperation success and sustainability [7] - the effects should be discussed regarding the paradox. The positive impact of trust has been considered as a general view [32,33]. Interestingly, this view does not always appear as the benefits of trust may be magnified or diminished under different contexts [14]. Due to the specific effects of network structure on sustainable competitive advantage [1,34], we propose that the contradictions may also be contingent on the embedded network of the distributor and the supplier. Therefore, our second research question is: How does interorganizational trust between the distributor and the supplier moderate the effects of structural holes in the distributor network and structural holes in the supplier network on the distributor sustainable competitive advantage?

To address these issues, we propose a unique approach by integrating social network theory and signaling theory to highlight the tensions inherent in the distributor network and the supplier network. We collected our data from the Chinese paper-making industry, in which firms are in urgent need to develop and sell novel, green products to improve competitive advantage. We strive to make the following contributions.

First, we offer a holistic understanding on how the different roles of the distributor network and the supplier network in acquiring knowledge, and further argue that the different features of two networks make structural holes exert different effects to improve sustainable competitive advantage $[25,28]$. Furthermore, our article extends signaling theory to argue that signals from the network structure of the partner could influence the focal distributor decision to cooperate with network partners. Based on social network theory, this article provides important and novel insights to the relationships between network structure in two types of networks and sustainable competitive advantage, and responds to Funk's [35] call that the applicability of different contingencies across different networks should be identified.

Second, we introduce the action mechanism of trust to influence the effects of structural holes in different networks on improving sustainable competitive advantage, which complement and enrich the studies on trust. Furthermore, by empirically examining the theoretical research of Afuah [15], who asserted that network structure and network conduct could influence the value of members 
in a network simultaneously, we propose that interorganizational trust (network conduct) would differently affect the effects of structural holes (network structure) in the distributor network and the supplier network to improve the distributor sustainable competitive advantage. As the combination of structural holes and mutual trust provides a new understanding for knowledge management, we also explore how the strategies of knowledge management influences the performance of social networks in this article [36-38].

Third, with rapid economic development in China, firms and the government must deal with high pollution and high resource-consumption. Developing and selling green products are the important channel for firms to satisfy the needs of both the customers and the government, and to improve sustainable competitive advantage [3,4]. In this article, we theoretically and empirically demonstrate how the distributor could leverage both the distributor network and supplier network to develop and sell novel, green products to improve sustainable competitive advantage, and how mutual trust could moderate the network-sustainable competitive advantage relationships in both networks. Thus, we enrich the boundary of both social network theory and sustainable competitive advantage literature.

\section{Theory and Hypotheses}

\subsection{The Urgent Need for Improving Sustainable Competitive Advantage}

To establish or improve sustainable competitive advantage, it is imperative to explore new routines including novel, green products, or opportunities to satisfy the needs of customers and the government $[3,39]$. However, it often costs a lot to pursue access to new knowledge and relevant resources [40,41]. In this case, the paradox between acquiring knowledge sources and interorganizational trust is vital for improving sustainable competitive advantage [15,17]. On the one hand, external knowledge sources could bring others' innovative ideas, and allow them to create new combinations of technologies and knowledge to develop novel, green products [42]. However, when the focal firm strives to acquire wide knowledge sources, it is hard to guarantee the quality of the acquired knowledge as opportunistic behaviors are common in the process of knowledge or information exchange based on weak relationships between the focal firm and the knowledge sources [43]. On the other hand, nothing has received more attention than trust regarding strategic cooperation $[19,33]$. Interorganizational trust can ensure the usefulness and quality of knowledge transfer [44]. Nevertheless, as it takes time to build mutual trust, the exchanged knowledge tends to lose novelty and diversity after this period [17].

\subsection{Network Structure and Signals of the Knowledge Background}

To solve this paradox, we first pay attention to the knowledge sources. Apart from differential informational advantages, social network structure, such as structural holes, could generate advantageous positions to control benefits from other actors [2,45]. The importance of social networks as external knowledge sources on sustainable competitive advantage has been widely examined in prior studies $[1,36]$. However, abundant existing literature regarding networks tends to focus on the focal firm and network partners in the same network $[46,47]$. However, this situation does not always exist. Network members are often involved in separate networks, which sometimes overlap with each other, instead of embedded in an isolated network [24,35]. As Phelps [2] (p. 891) suggests, "ties to partners with dissimilar knowledge stocks provide a firm with access to diverse information and know-how, independent of the structure of its local network". Consequently, the focal firm should place emphasis on both its own network and the latent partners' network for knowledge acquisition. In particular, the supply chain management literature has long acknowledged the benefit of engaging suppliers and distributors to improve sustainable competitive advantage [48-50] and the relevant literature stream has paid more attention to how social network acts in a supply chain and how a supply chain network influences sustainable competitive advantage [50-52]. For a focal distributor, it's necessary to take notice of both its own network and its supplier network $[28,53]$. 
However, how does one identify the knowledge sources from the supplier network? Signaling theory is rooted in the idea of reducing asymmetric information between two parties, which credibly suggests the conveyance of some information from one party to another [54]. Different types of signals could transfer reputation, patents, quality, and other relevant information about the background and status of the signal source $[55,56]$. The network structure generates the important type of signal to show the knowledge background [26,57]. From the signals suggested by the supplier network structure, the focal distributor could identify whether the supplier could provide potential, useful knowledge, and then absorb the specific knowledge which could be integrated to develop novel, green products to satisfy the needs of the customers and the government. That is to say, the focal distributor could also recognize the potential knowledge acquisition from the supplier network to develop and sell novel, green products to improve sustainable competitive advantage.

\subsection{Structural Holes in Two Types of Networks}

Structural holes, in the context of the widely concerned network structure, refer to the absence of a link between two contacts who are both linked to an actor [30]. Abundant structural holes facilitate knowledge acquisition in several mechanisms [58,59]. In the distributor ego network, structural holes can bring diverse, timely and non-redundant information and knowledge [23,60]. In addition, the focal distributor spanning structural holes gains brokerage and control (described as "giving certain players an advantage in negotiating their relationships") benefits from an advantageous position $[61,62]$. Apart from actor's capability to control the information flow since the disconnected groups communicate only through these brokers [63], advantages to such a position also include control and participation in resource diffusion [34], potential risks and uncertainty reduction [64], and the non-redundancy benefits of the network structure [57]. Third, the broker will enhance its own status, considered as "a trade-off that will add structural holes to the network and ties that augment the actor's status" [65], which raises sustainable competitive advantage [66]. Others positioned in networks with more structural holes have an increased informal influence [67] and possess advantages through their access to networks rich in information about novel business opportunities such as new or popular green products [68]. Abundant structural holes could facilitate knowledge acquisition and creation by controlling novel information flows [69]. All the above enrich the knowledge and status foundation of the distributor and promote its motivation and probability to develop and sell novel, green products to improve sustainable competitive advantage. Thus, we suggest:

Hypothesis 1a. Structural holes in the distributor network are positively related to the distributor sustainable competitive advantage.

In the supplier network, structural holes also offer the supplier with the knowledge and status advantage mentioned above. A positive signal provides the dominance of structural holes to the distributor [70], and even amplifies the quality of the network structure [71]. By the signal, the resources or knowledge potentially obtained from the supplier network would be evaluated by the distributor, which has communications with the supplier [27]. Then, the distributor could learn how to develop and sell green products with the supplier to meet the needs of customers and government. More structural holes in the supplier network signals more potential novel, green products [26], which could further improve the distributor sustainable competitive advantage. Therefore, we suggest:

Hypothesis $\mathbf{1 b}$. Structural holes in the supplier network are positively related to the distributor sustainable competitive advantage. 


\subsection{The Contingent Effects of Mutual Trust between the Distributor and the Supplier}

To solve this paradox, we should also investigate how interorganizational mutual trust works under these contexts, as mutual trust can ensure the usefulness and quality of knowledge transfer [44]. For the usage of structural holes in the distributor network, we argue that mutual trust between the distributor and the supplier would negatively influence the distributor sustainable competitive advantage. First, in the distributor external ego network, abundant resources and knowledge acquired from the structural holes stem from the distributor network members, which might include the supplier [23,72]. That is to say, it is almost impossible for the distributor to utilize the interorganizational mutual trust with the supplier to control the latent risks and opportunism in the knowledge exchange [32,73]. Trust with the supplier cannot improve the efficiency of the distributor knowledge acquisition from the structural holes. Moreover, as it needs high costs to maintain mutual trust [31,74], that decreases the effects of deep trust with the suppliers, which would then impair the efficiency of improving sustainable competitive advantage through developing and selling green products. Thus, we suggest:

Hypothesis 2a. Mutual trust negatively moderates the relationship between structural holes in the distributor network and the distributor sustainable competitive advantage.

By contrast, the interorganizational mutual trust between the distributor and the supplier impacts differently on the structural holes in the supplier network. To absorb the knowledge from the supplier network, the distributors must establish deep relationships and trust with the supplier [75]. This is because the supplier is the main source of knowledge and resources. In addition, the signal, generated from structural holes in the supplier network, could reduce the uncertainty and adverse selection risks about the accessible resources and knowledge [26]. The deeper the interorganizational trust between the distributor and the supplier, the more precisely the distributor could evaluate the potential resources and knowledge from the supplier [48,74]. Trust can improve the efficiency to utilize the structural holes from the supplier network to develop and sell novel, green products, which could contribute to improve sustainable competitive advantage. Therefore, we suggest:

Hypothesis 2b. Mutual trust positively moderates the relationship between structural holes in the supplier network and the distributor sustainable competitive advantage.

\section{Method}

\subsection{Sample and Data Collection}

We collected questionnaire survey data from the paper-making industry in China to show how structural holes of distributors' suppliers could improve sustainable competitive advantage. We consider China as an ideal situation for the following reasons. First, the Chinese place emphasis on "guanxi" development, and the effects of network are important in China [76]. Second, as the country continues its economic transition from the planning to the socialist market system, Chinese contexts are attracting increasing interest from around the world [77], and network structure should show different characteristics from western countries [47]. At the same time, high economic development increases the needs for green products. In particular for high pollution and high-consuming industries such as the paper-making industry, it is imperative for firms to develop and sell green products to improve sustainable competitive advantage.

We developed a back-translated questionnaire according to extant literature and in-depth consultations with 10 corporate executives in the paper-making industry. To ensure reliability and validity, we followed the widely used method of prior research [50,78]. In addition, we adopted a face-to-face interview method using trained interviewers to ensure the quality of data collection. 
A pilot study was also conducted in 5 suppliers and 2 distributors. They were excluded from the final sample of this article, and the initial questionnaire was revised based on feedback from the pilot study.

We adopted a three-phase procedure in data collection. First, we randomly chose 12 paper mills and contacted them. In the interview, the senior managers in charge of marketing were asked to fill out the questionnaire about their ego network, list their important distributors and rate each distributor. Then we asked these suppliers to introduce these suppliers to us. In this phase, we obtained questionnaires involving 150 distributors. In the second phase, with the support of the suppliers, we interviewed these 150 distributors. They were located in 24 municipalities and provinces in China. The geographical location of our sampled suppliers covered almost all China. Likewise, we emailed and asked the senior managers in charge of marketing to fill out the questionnaire about their ego network, list their important suppliers and rate the questionnaire about each supplier. Apart from the suppliers investigated before, we also asked them to introduce other suppliers to us. In this phase, we acquired questionnaires involving 25 suppliers. In the third, with the assistance of the distributors, we contacted the other 13 suppliers. Then the senior managers in charge of marketing were asked to fill out the questionnaire about their ego network and rate these distributors. In the end, 25 suppliers and 150 distributors participated in our survey. Finally, by deleting the missing or unqualifying questionnaires, we have a total of 122 matched sets of questionnaires involving 18 suppliers and 97 distributors.

\subsection{Measurements of Dependent Variable}

The distributor sustainable competitive advantage. In this article, we adopted the distributor green products sales growth to measure the distributor sustainable competitive advantage, which is computed by

(green products sales-green products sales in the last year)/green products sales in the last year.

\subsection{Measurements of Independent Variables}

Structural holes. Structural holes referred to the absence of a link between two contacts who are both linked to an actor [30,68]. We computed the efficiency measure from Burt [30] that reflects the actor's access to structural holes. In our survey, we adopted the name-generator procedures [30,79], and respondents should give no more than ten firms which are most important. Then the respondents were asked to evaluate the relationships between them and their partners and as well as among their partners which they listed. That is to say, they should indicate, "How frequently do you interact with this organization?" or "How frequently do these two organizations interact with each other?" (0. "Almost none"; 1 . "1-3 times a year"; 2 . "1-2 times a quarter"; 3. "1-3 times a month"; 4. "More than 1 time a week"). We calculated efficiency in UCINET VI using the following formula [80]:

$$
\text { efficiency }_{i}=\left[\sum_{j}\left(1-\sum_{q} p_{i q} m_{j q}\right)\right] / N_{i}, q \neq i, j
$$

where $p_{i q}$ is the proportion of the actor organization $i$ is ties invested in connection with organization $q$, and $m_{j q}$ is the marginal strength of the relationship between organization $j$ and organization $q$, and $N_{i}$ is the total number of contacts for organization $i$. According to network type, we could obtain both the distributor structural holes and the supplier structural holes.

\subsection{Measurement of Moderating Variable}

Mutual Trust. Both the distributor and the supplier managers rated the four-item scale adapted from Johnsen and Ford [81] as well as Li, Poppo and Zhou [82] to evaluate mutual trust between each other. The items were rated on a 5-point Likert scale ranging from strongly disagree (1) to strongly agree (5). In addition, this variable was averaged by the responses of the matched pair of the distributor managers and the supplier managers. The distributor managers rated the following items, "(1) We 
have confidence in the capability of the supplier"; "(2) Even if we do not check, the supplier will also take the initiative to assume its responsibilities"; "(3) We pay more attention to the commitment"; and "(4) We believe that the supplier will provide the necessary help". The supplier managers should rate the following items. "(1) We have confidence in the capability of the distributor"; "(2) Even if we do not check, the distributor will also take the initiative to assume its responsibilities"; "(3) We pay more attention to the commitment"; and "(4) We believe that the distributor will provide the necessary help". We adopted Cronbach's alpha to examine data reliability. The Cronbach's alpha of trust rated by the distributor managers is 0.90 while the Cronbach's alpha of trust rated by the supplier managers is 0.91 . Hence, these measures demonstrate adequate internal reliability $[78,83]$. To assess rater agreement, we coded a subsample of 70 matched pairs randomly selected apart from the complete sample. The kappa value was 0.92 , which showed a high degree of inter-rater reliability [84].

\subsection{Measurements of Control Variables}

We also controlled for the following variables: (1) firm age, using the logarithm of distributor firm age; (2) firm size, using the logarithm of the distributor employees; (3) relationship length, using the years from the relationships established by the matched pair of the distributor and supplier.

\section{Results and Analysis}

Table 1 presents the descriptive statistics and Pearson's correlations of all hypothesized and control variables. In addition, Table 2 shows the regression results.

Table 1. Descriptive Statistics and Correlations.

\begin{tabular}{lcccccccc}
\hline \multicolumn{1}{c}{ Variable } & Mean & S.D. & $\mathbf{1}$ & $\mathbf{2}$ & $\mathbf{3}$ & $\mathbf{4}$ & $\mathbf{5}$ & $\mathbf{6}$ \\
\hline 1. Firm age & 0.97 & 0.39 & & & & & & \\
2. Firm size & 1.56 & 0.48 & $0.49^{* *}$ & & & & & \\
3. Relationship length & 7.83 & 5.98 & $0.47^{* *}$ & $0.21^{*}$ & & & & \\
4. The distributor structural holes & 0.35 & 0.29 & 0.05 & 0.01 & 0.13 & & & \\
5. The supplier structural hole & 0.52 & 0.18 & -0.09 & -0.09 & 0.08 & -0.06 & & \\
6. Mutual trust & 4.38 & 0.41 & -0.01 & 0.06 & 0.05 & -0.06 & -0.02 & \\
7. Sustainable competitive advantage & 0.16 & 0.48 & 0.07 & 0.04 & 0.03 & 0.16 & 0.01 & 0.05 \\
\hline \multicolumn{8}{c}{$p<0.05 ; * * 0.01}$. \\
\end{tabular}

Table 2. Test of Hypotheses.

\begin{tabular}{|c|c|c|c|}
\hline Variables & Model 1 & Model 2 & Model 3 \\
\hline Firm age & 0.100 & 0.111 & $0.154^{+}$ \\
\hline Firm size & $0.267 * *$ & $0.257^{* *}$ & $0.229 * *$ \\
\hline Relationship length & $-0.269 * * *$ & $-0.204^{* * *}$ & $-0.244^{* * *}$ \\
\hline The distributor structural holes & & $0.128^{\dagger}$ & $0.169^{* *}$ \\
\hline The supplier structural holes & & $0.477^{* * *}$ & $0.473^{* * *}$ \\
\hline Trust & & & $0.206^{* * *}$ \\
\hline The distributor structural holes * Trust & & & $-0.212^{* * *}$ \\
\hline The supplier structural holes * Trust & & & $0.172^{* *}$ \\
\hline$R$ Square & 0.118 & 0.350 & 0.446 \\
\hline Adjusted $R$ Square & 0.072 & 0.291 & 0.337 \\
\hline$F$ & $2.559 *$ & $5.975^{* * *}$ & $4.072 * * *$ \\
\hline
\end{tabular}

In Table 2, Model 1 is the base model with control variables. We first hypothesized the positive effects of structural holes in the distributor and supplier networks on sustainable competitive advantage. To test these hypotheses, we turn to the main effects in Model 2. In this model, the coefficient for the distributor structural holes is positive and marginally significant $(b=0.128, p<0.1)$. In the full Model 3, the coefficient for the distributor structural holes is positive and statistically significant 
$(b=0.169, p<0.01)$. Thus, the empirical results provide strong support for Hypothesis 1a. Meanwhile, in Model 2, the coefficient for the supplier structural holes is positive and statistically significant $(b=0.477, p<0.001)$. In the full Model 3 , the coefficient for the supplier structural holes is also positive and statistically significant $(b=0.473, p<0.001)$. Thus, Hypothesis $1 \mathrm{~b}$ is strongly supported.

In addition, we add mutual trust and the interaction terms to test Hypotheses $2 \mathrm{a}$ and $2 \mathrm{~b}$. In the full Model 3, the interaction between the distributor structural holes and mutual trust is negative and statistically significant $(b=-0.212, p<0.001)$, strongly supporting Hypotheses 2a. Moreover, the interaction between the supplier structural holes and mutual trust is positive and statistically significant $(b=0.172, p<0.01)$, which provides strong support for Hypotheses $2 b$.

\section{Discussion}

\subsection{Summary}

Confronted with the urgent green requirements of customers and government, firms in high-pollution and high-resource-consuming industries must make changes and adopt green strategies to develop and sell green products to improve sustainable competitive advantage. Our article sheds light on the effects of structural holes in the distributor network as well as structural holes in the supplier network on the distributor sustainable competitive advantage in the paper-making industry. Moreover, we intend to indicate how mutual trust of the distributor and the supplier integrating both networks influences the distributor sustainable competitive advantage. By integrating the distributor network as the knowledge background per se, the supplier network as the signal of latent knowledge sources, and mutual trust as the efficiency of knowledge transfer, our findings have considerable theoretical and managerial implications for future research on social network theory and signaling theory. Our empirical results from the Chinese paper-making industry demonstrate that: (1) Structural holes in the distributor network could contribute to improving the distributor sustainable competitive advantage; (2) Structural holes in the supplier network could contribute to improving the distributor sustainable competitive advantage; (3) Mutual trust could negatively moderate the relationship between structural holes in the distributor network and the distributor sustainable competitive advantage; and (4) Mutual trust could positively moderate the relationship between structural holes in the supplier network and the distributor sustainable competitive advantage.

\subsection{Theoretical Contributions}

Our findings provide important theoretical contributions. First, we move the research a step forward by pointing out the necessity of investigating several networks of the focal firms simultaneously instead of an isolated network [25,47]. In this article, we examine how network structure such as structural holes in both the distributor network and the supplier network could improve the distributor sustainable competitive advantage, which is closer to the action mechanism of the distributor-supplier system. Importantly, we suggest the positive effect of structural holes in the distributor network is based on the intrinsic effects of structural holes, while the positive effect of structural holes in the supplier network is derived from an intentional knowledge search by the focal distributor. Extending previous conceptual works [1,23], our findings provide a more nuanced understanding of the different mechanisms of structural holes in these two types of networks, and which also responds to the call from Funk [35] who suggests that the applicability of different contingencies across different networks should be identified.

Further, existing studies tend to explore the conflict effects of structural holes under various contexts $[58,68]$. However, limited to the network attributes or external environments of the focal firm, the action mechanism of structural holes is difficult to approach more deeply. In this article, we introduce the signaling theory to show how the distributor could select the potential supplier and utilize the advantage of its external ego network to improve sustainable competitive advantage. By considering the structural holes in the supplier network as the signal of available knowledge to 
the focal distributor, we provide a new angle to explore the action mechanism of network structure, specifically structural holes. That is to say, the signaling theory expands the boundary of social network theory. Furthermore, the integration of social network theory and signaling theory could reflect the action mechanism of the distributor-supplier system more distinctly, which enhances the efficiency and utility of the existing research field.

Our third contribution lies in theoretically providing a more comprehensive framework consisting of structural holes and mutual trust to illustrate the combined effects of network structure and network conduct on sustainable competitive advantage. According to the theoretical research of Afuah [15], asserting that network structure and network conduct could influence the value of members in network simultaneously, we empirically examine it by considering structural holes as network structure, and trust as network conduct. Mutual trust between the distributors and suppliers exerts opposite effects in modifying the effects of structural holes in the distributor network and the supplier network on the distributor sustainable competitive advantage. Specifically, mutual trust weakens the positive effect of structural holes in the distributor network but improves the positive effect of structural holes in the supplier network. Based on the distributor-supplier perspective and social network theory, these results show that structural holes and mutual trust as two important domains should to be considered together, and examining the impact of trust on structural holes in different networks provides another new, important angle for a deeper understanding of the action mechanism of structural holes. Thus, our article is important for understanding the link between structural holes in both the distributor network and supplier network, and mutual trust in improving sustainable competitive advantage. Furthermore, the combination of structural holes and mutual trust provides a new understanding for knowledge management, and our article theoretically and empirically demonstrates how the strategies of knowledge management can have an impact on firm performance and on the performance of their networks [36-38].

Finally, with rapid economic development, more attention from the government to residents is being focused on sustainable development [3,4], especially for rising powers such as China $[6,50,85]$. The government is taking measures to limit the development of high-pollution and high-resource-consuming industries and encourage the development of green industries. Meanwhile, with the rising of public awareness of environmental protection, consumers have increasing preferences towards green products [39]. To meet the increasingly stringent environmental regulations from the administrative authority and the growing environmental needs of consumers, firms can take the "green" strategy and acquire sustainable competitive advantage. Thus, based on the data of 122 matched pairs of suppliers and distributors from the Chinese paper-making industry, we theoretically and empirically demonstrate how the distributor could leverage both the distributor network and supplier network to develop and sell novel, green products to improve sustainable competitive advantage. Mutual trust could negatively moderate the network-sustainable competitive advantage relationship in the distributor network, while mutual trust could positively moderate the network-sustainable competitive advantage relationship in the supplier network. Thus, we integrate social network theory and sustainable competitive advantage literature to enrich their research boundary.

\subsection{Managerial Implications}

Facilitating the antecedents of sustainable competitive advantage has become an increasingly important part of management practice for firms to deal with rapidly growing green requirements of customers and government, especially for firms in high-pollution and high-resource-consuming industries. In this article, we show the different action mechanisms of structural holes in the distributor network and the supplier network to improve competitive advantage, based on the positive impact of structural holes both in these two types of networks on the distributor sustainable competitive advantage. To improve sustainable competitive advantage, the managers of the focal distributor should span more structural holes in the distributor ego network, and they could try to utilize knowledge from the supplier for the signal of abundant structural holes in the supplier ego network. Furthermore, 
the moderating roles of mutual trust between the distributor and the supplier show the double-bladed sword effects, and the managers need to leverage structural holes suitably. When mutual trust is low, the focal distributor could make use of structural holes in its ego network easily but find it hard to utilize the knowledge from the structural holes in the supplier network. Contrarily, high mutual trust is needless for the structural holes in the distributor network but plays an important role in acquiring knowledge from structural holes in the supplier network. Finally, policy makers could pay more attention to the cooperation between the distributors and the suppliers and make relevant policies such as establishing efficient cooperation service platforms, to support their sustainable competitive advantage improvement. Overall, according to their ambition to improve sustainable competitive advantage, the managers of the focal distributor could make different decisions based on network structure and network conduct in the distributor network and the supplier network. Through both networks and different levels of mutual trust, the managers could find the best channel to develop and sell novel, green products and sustainably improve competitive advantage.

\subsection{Future Research Directions and Limitations}

Even with its contributions, this article is not without limitations, which offer opportunities for future improvement. First, our hypotheses are only tested in China, which raises the issue of unobserved heterogeneity. To address the potential influence of unobserved variables, we have carefully sampled and included market-relevant control variables in our models. However, it may still differ in other aspects, such as unobserved cultural, economic, and political differences [58,86], which is hard to capture. Future work could examine the influence of our hypotheses in different countries to further rule out potential alternative explanations. Second, we only focus on how to improve sustainable competitive advantage. However, the outcome aspect is also important and interesting. Therefore, future studies can explore whether different action mechanisms of structural holes could affect other dependent variables. Third, our article uses cross-sectional data to test our hypotheses, and further research could adopt a longitudinal approach and a large sample to examine these relationships. Finally, our article focuses on the features of the external ego network of the focal distributor without subdivision. However, we have not considered other networks such as the intra-industry network, inter-industry network, regional industry, etc. Future research could take other kinds of networks into account and show the relationships' substitution or complementarity.

Author Contributions: Conceptualization, H.W. and W.L.; Data curation, P.H.; Writing-original draft, H.W.; Writing-review \& editing, W.L.

Funding: This research was funded by Soft Science Projects of Shanghai (17692180302) and Zhejiang Provincial Natural Science Foundation of China (LQ18G030010 and LQ18G010005).

Conflicts of Interest: We declare that we have no conflict of interest.

\section{References}

1. Ge, H.; Chen, S.; Chen, Y. International alliance of green hotels to reach sustainable competitive advantages. Sustainability 2018, 10, 573. [CrossRef]

2. Phelps, C.C. A longitudinal study of the influence of alliance network structure and composition on firm exploratory innovation. Acad. Manag. J. 2010, 53, 890-913. [CrossRef]

3. He, Q.; Fang, H.; Ji, H.; Fang, S. Environmental inequality in China: A "pyramid model" and nationwide pilot analysis of prefectures with sources of industrial pollution. Sustainability 2017, 9, 1871. [CrossRef]

4. Tang, X.; McLellan, B.C.; Snowden, S.; Zhang, B.; Höök, M. Dilemmas for China: Energy, economy and environment. Sustainability 2015, 7, 5508-5520. [CrossRef]

5. Tripsas, M. Unraveling the process of creative destruction: Complementary assets and incumbent survival in the typesetter industry. Strateg. Manag. J. 1997, 18, 119-142. [CrossRef]

6. Liu, W.; Hu, G.; Tang, L.; Wang, Y. China's global growth in social science research: Uncovering evidence from bibliometric analyses of SSCI publications (1978-2013). J. Informetr. 2015, 9, 555-569. [CrossRef]

7. Koza, M.P.; Lewin, A.Y. The co-evolution of strategic alliances. Organ. Sci. 1998, 9, 255-264. [CrossRef] 
8. Yang, H.; Lin, Z.; Peng, M.W. Behind acquisitions of alliance partners: Exploratory learning and network embeddedness. Acad. Manag. J. 2011, 54, 1069-1080. [CrossRef]

9. Kim, C.; Kim, S.W.; Kang, H.J. Driving sustainable competitive advantage in the mobile industry: Evidence from US wireless carriers. Sustainability 2016, 8, 659. [CrossRef]

10. Yu, C.; Zhang, Z.; Lin, C.; Wu, Y.J. Knowledge creation process and sustainable competitive advantage: The role of technological innovation capabilities. Sustainability 2017, 9, 2280. [CrossRef]

11. Jiang, C.; Zhang, Y.; Bu, M.; Liu, W. The effectiveness of government subsidies on manufacturing innovation: Evidence from the new energy vehicle industry in China. Sustainability 2018, 10, 1692. [CrossRef]

12. Chiang, Y.H.; Hung, K.P. Exploring open search strategies and perceived innovation performance from the perspective of inter-organizational knowledge flows. RED Manag. 2010, 40, 292-299.

13. Hoang, H.A.; Rothaermel, F.T. Leveraging internal and external experience: Exploration, exploitation, and R\&D project performance. Strateg. Manag. J. 2010, 31, 734-758.

14. Perrone, V.; Zaheer, A.; McEvily, B. Free to be trusted? Organizational constraints on trust in boundary spanners. Organ. Sci. 2003, 14, 422-439. [CrossRef]

15. Afuah, A. Are network effects really all about size? The role of structure and conduct. Strateg. Manag. J. 2013, 34, 257-273. [CrossRef]

16. Granovetter, M.S. The strength of weak ties. Am. J. Sociol. 1973, 78, 1360-1380. [CrossRef]

17. Becerra, M.; Lunnan, R.; Huemer, L. Trustworthiness, risk, and the transfer of tacit and explicit knowledge between alliance partners. J. Manag. Stud. 2008, 45, 691-713. [CrossRef]

18. Pfeffer, J.; Fong, C.T. Building organization theory from first principles: The self-enhancement motive and understanding power and influence. Organ. Sci. 2005, 16, 372-388. [CrossRef]

19. Gulati, R.; Nohria, N.; Zaheer, A. Strategic networks. Strateg. Manag. J. 2000, 21, 203-215. [CrossRef]

20. Mazzola, E.; Perrone, G.; Kamuriwo, D.S. The interaction between inter-firm and interlocking directorate networks on firm's new product development outcomes. J. Bus. Res. 2016, 69, 672-682. [CrossRef]

21. Wang, H.; Zhao, J.; Li, Y.; Li, C. Network centrality, organizational innovation, and performance: A meta-analysis. Can. J. Adm. Sci. 2015, 32, 146-159. [CrossRef]

22. Gilsing, V.; Nooteboom, B.; Vanhaverbeke, W.; Duysters, G.; van den Oord, A. Network embeddedness and the exploration of novel technologies: Technological distance, betweenness centrality and density. Res. Policy 2008, 37, 1717-1731. [CrossRef]

23. Ahuja, G. Collaboration networks, structural holes, and innovation: A longitudinal study. Adm. Sci. Q. 2000, 45, 425-455. [CrossRef]

24. Gonzalez, G.R.; Claro, D.P.; Palmatier, R.W. Synergistic effects of relationship managers' social networks on sales performance. J. Mark. 2014, 78, 76-94. [CrossRef]

25. Sytch, M.; Tatarynowicz, A. Exploring the locus of invention: The dynamics of network communities and firms' invention productivity. Acad. Manag. J. 2014, 57, 249-279. [CrossRef]

26. Ozmel, U.; Reuer, J.J.; Gulati, R. Signals across multiple networks: How venture capital and alliance networks affect interorganizational collaboration. Acad. Manag. J. 2013, 56, 852-866. [CrossRef]

27. Hoehn-Weiss, M.N.; Karim, S. Unpacking functional alliance portfolios: How signals of viability affect young firms' outcomes. Strateg. Manag. J. 2014, 35, 1364-1385. [CrossRef]

28. Dong, M.C.; Liu, Z.; Yu, Y.; Zheng, J.H. Opportunism in distribution networks: The role of network embeddedness and dependence. Prod. Oper. Manag. 2015, 24, 1657-1670. [CrossRef]

29. Kim, D.Y. Understanding supplier structural embeddedness: A social network perspective. J. Oper. Manag. 2014, 32, 219-231. [CrossRef]

30. Burt, R.S. Structural Holes: The Social Structure of Competition; Harvard University Press: Cambridge, MA, USA, 1992.

31. Rost, K. The strength of strong ties in the creation of innovation. Res. Policy 2011, 40, 588-604. [CrossRef]

32. Dyer, J.H.; Chu, W. The role of trustworthiness in reducing transaction costs and improving performance: Empirical evidence from the United States, Japan, and Korea. Organ. Sci. 2003, 14, 57-68. [CrossRef]

33. Krishnan, R.; Martin, X.; Noorderhaven, N.G. When does trust matter to alliance performance? Acad. Manag. J. 2006, 49, 894-917. [CrossRef]

34. Burt, R.S. The network structure of social capital. Res. Organ. Behav. 2000, 22, 345-423. [CrossRef]

35. Funk, R.J. Making the most of where you are: Geography, networks, and innovation in organizations. Acad. Manag. J. 2014, 57, 193-222. [CrossRef] 
36. Bhatt, G.D. Organizing knowledge in the knowledge development cycle. J. Knowl. Manag. 2000, 4, 15-26. [CrossRef]

37. Centobelli, P.; Cerchione, R.; Esposito, E. Aligning enterprise knowledge and knowledge management systems to improve efficiency and effectiveness performance: A three-dimensional Fuzzy-based decision support system. Expert Syst. Appl. 2018, 91, 107-126. [CrossRef]

38. Centobelli, P.; Cerchione, R.; Esposito, E. How to deal with knowledge management misalignment: A taxonomy based on a 3D fuzzy methodology. J. Knowl. Manag. 2018, 22, 538-566. [CrossRef]

39. Yang, L.; Dong, S. Sustainable product strategy in apparel industry with consumer behavior consideration. Sustainability 2017, 9, 920. [CrossRef]

40. Park, S.H.; Chen, R.R.; Gallagher, S. Firm resources as moderators of the relationship between market growth and strategic alliances in semiconductor start ups. Acad. Manag. J. 2002, 45, 527-545.

41. Rothaermel, F.T.; Deeds, D.L. Exploration and exploitation alliances in biotechnology: A system of new product development. Strateg. Manag. J. 2004, 25, 201-221. [CrossRef]

42. Zhou, K.Z.; Li, C.B. How knowledge affects radical innovation: Knowledge base, market knowledge acquisition, and internal knowledge sharing. Strateg. Manag. J. 2012, 33, 1090-1102. [CrossRef]

43. Perry-Smith, J.E. Social yet creative: The role of social relationships in facilitating individual creativity. Acad. Manag. J. 2006, 49, 85-101. [CrossRef]

44. Levin, D.Z.; Cross, R. The strength of weak ties you can trust: The mediating role of trust in effective knowledge transfer. Manag. Sci. 2004, 50, 1477-1490. [CrossRef]

45. Rowley, T.; Behrens, D.; Krackhardt, D. Redundant governance structures: An analysis of structural and relational embeddedness in the steel and semiconductor industries. Strateg. Manag. J. 2000, 21, 369-386. [CrossRef]

46. Baum, J.A.C.; Calabrese, T.; Silverman, B.S. Don't go it alone: Alliance network composition and startups' performance in Canadian biotechnology. Strateg. Manag. J. 2000, 21, 267-294. [CrossRef]

47. Lin, J.; Peng, M.W.; Yang, H.B.; Sun, S. How do networks and learning drive M\&As? An institutional comparison between china and the United States. Strateg. Manag. J. 2009, 30, 1113-1132.

48. Bányai, Á.; Bányai, T.; Illés, B. Optimization of consignment-store-based supply chain with black hole algorithm. Complexity 2017. [CrossRef]

49. Carter, C.R.; Rogers, D.S. A framework of sustainable supply chain management: Moving toward new theory. Int. J. Phys. Distrib. Logist. Manag. 2008, 38, 360-387. [CrossRef]

50. Gao, G.Y.; Xie, E.; Zhou, K.Z. How does technological diversity in supplier network drive buyer innovation? Relational process and contingencies. J. Oper. Manag. 2015, 36, 165-177. [CrossRef]

51. Bányai, T. Supply chain optimization of outsourced blending technologies. J. Appl. Econ. Sci. 2017, 4, 960-976.

52. Linton, J.D.; Klassen, R.; Jayaraman, V. Sustainable supply chains: An introduction. J. Oper. Manag. 2007, 25, 1075-1082. [CrossRef]

53. Lassar, W.M.; Kerr, J.L. Strategy and control in supplier-distributor relationships: An agency perspective. Strateg. Manag. J. 1996, 17, 613-632. [CrossRef]

54. Spencer, J.W. Global gatekeeping, representation, and network structure a longitudinal analysis of regional and global knowledge-diffusion networks. J. Int. Bus. Stud. 2003, 34, 428-442. [CrossRef]

55. Connelly, B.L.; Certo, S.T.; Ireland, R.D.; Reutzel, C.R. Signaling theory: A review and assessment. J. Manag. 2011, 37, 39-67. [CrossRef]

56. Reuer, J.J.; Ragozzino, R. The choice between joint ventures and acquisitions: Insights from signaling theory. Organ. Sci. 2012, 23, 1175-1190. [CrossRef]

57. Koka, B.R.; Prescott, J.E. Designing alliance networks: The influence of network position, environmental change, and strategy on firm performance. Strateg. Manag. J. 2008, 29, 639-661. [CrossRef]

58. Batjargal, B.; Hitt, M.; Tsui, A.; Arregle, J.L.; Webb, J.; Miller, T. Institutional polycentrism, entrepreneurs' social networks and new venture growth. Acad. Manag. J. 2013, 56, 1024-1049. [CrossRef]

59. Bell, G.G. Clusters networks, and firm innovativeness. Strateg. Manag. J. 2005, 26, 287-295. [CrossRef]

60. Owen-Smith, J.; Powell, W.W. Knowledge networks as channels and conduits: The effects of spillovers in the boston biotechnology community. Organ. Sci. 2004, 15, 5-21. [CrossRef]

61. Koka, B.R.; Prescott, J.E. Strategic alliances as social capital: A multidimensional view. Strateg. Manag. J. 2002, 23, 795-816. [CrossRef] 
62. Soh, P.H. Network patterns and competitive advantage before the emergence of a dominant design. Strateg. Manag. J. 2010, 31, 438-461. [CrossRef]

63. Fernandez, R.M.; Gould, R.V. A dilemma of state power: Brokerage and influence in the national health policy domain. Am. J. Sociol. 1994, 99, 1455-1491. [CrossRef]

64. Podolny, J.M. Networks as pipes and prisms of the market. Am. J. Sociol. 2001, 107, 33-60. [CrossRef]

65. Podolny, J.M. Status Signals: A Sociological Study of Market Competition; Princeton University Press: Princeton, NJ, USA, 2005.

66. Zaheer, A.; Soda, G. Network evolution: The origins of structural holes. Adm. Sci. Q. 2009, 54, 1-31. [CrossRef]

67. Lechner, C.; Frankenberger, K.; Floyd, S.W. Task contingencies in the curvilinear relationships between intergroup networks and initiative performance. Acad. Manag. J. 2010, 53, 865-889. [CrossRef]

68. Shipilov, A.V.; Li, S.X. Can you have your cake and eat it too? Structural holes' influence on status accumulation and market performance in collaborative networks. Adm. Sci. Q. 2008, 53, 73-108. [CrossRef]

69. Hargadon, A.; Sutton, R.I. Technology brokering and innovation in a product development firm. Adm. Sci. Q. 1997, 42, 716-749. [CrossRef]

70. Ketokivi, M.; Castaner, X. Strategic planning as an integrative device. Adm. Sci. Q. 2004, 49, 337-365.

71. Phelps, C.; Heidl, R.; Wadhwa, A. Knowledge, networks, and knowledge networks: A review and research agenda. J. Manag. 2012, 38, 1115-1166. [CrossRef]

72. Zaheer, A.; Bell, G.G. Benefiting from network position: Firm capabilities, structural holes, and performance. Strateg. Manag. J. 2005, 26, 809-825. [CrossRef]

73. Uzzi, B. Social structure and competition in interfirm networks: The paradox of embeddedness. Adm. Sci. Q. 1997, 42, 35-67. [CrossRef]

74. Lazzarini, S.G.; Miller, G.J.; Zenger, T.R. Dealing with the paradox of embeddedness: The role of contracts and trust in facilitating movement out of committed relationships. Organ. Sci. 2008, 19, 709-728. [CrossRef]

75. Polidoro, F.; Ahuja, G.; Mitchell, W. When the social structure overshadows competitive incentives: The effects of network embeddedness on joint venture dissolution. Acad. Manag. J. 2011, 54, 203-223. [CrossRef]

76. Lee, D.Y.; Tsang, E.W. The effects of entrepreneurial personality, background and network activities on venture growth. J. Manag. Stud. 2001, 38, 583-602. [CrossRef]

77. Liu, W.; Tang, L.; Gu, M.; Hu, G. Feature report on China: A bibliometric analysis of China-related articles. Scientometrics 2015, 102, 503-517. [CrossRef]

78. Li, Y.; Li, P.P.; Wang, H.; Ma, Y. How Do Resource Structuring and Strategic Flexibility Interact to Shape Radical Innovation? J. Prod. Innov. Manag. 2017, 34, 471-491. [CrossRef]

79. Rodan, S.; Galunic, C. More than network structure: How knowledge heterogeneity influences managerial performance and innovativeness. Strateg. Manag. J. 2004, 25, 541-562. [CrossRef]

80. Borgatti, S.P.; Everett, M.G.; Freeman, L.C. Ucinet for Windows: Software for Social Network Analysis; Analytic Technologies: Harvard, MA, USA, 2002.

81. Johnsen, R.E.; Ford, D. Interaction capability development of smaller suppliers in relationships with larger customers. Ind. Mark. Manag. 2006, 35, 1002-1015. [CrossRef]

82. Li, J.J.; Poppo, L.; Zhou, K.Z. Relational mechanisms, formal contracts, and local knowledge acquisition by international subsidiaries. Strateg. Manag. J. 2010, 31, 349-370. [CrossRef]

83. Nunnally, J.C. Psychometric Theory, 2nd ed.; McGraw-Hill Book Company: New York, NY, USA, 1978.

84. Cohen, J.A. A coefficient of agreement for nominal scales. Educ. Psychol. Meas. 1960, 20, 37-46. [CrossRef]

85. Tang, L.; Shapira, P. China-US scientific collaboration in nanotechnology: Patterns and dynamics. Scientometrics 2011, 88, 1-16. [CrossRef]

86. Markóczy, L.; Sun, S.L.; Peng, M.W.; Shi, W.; Ren, B. Social network contingency, symbolic management, and boundary stretching. Strateg. Manag. J. 2013, 34, 1367-1387. [CrossRef]

(C) 2018 by the authors. Licensee MDPI, Basel, Switzerland. This article is an open access article distributed under the terms and conditions of the Creative Commons Attribution (CC BY) license (http://creativecommons.org/licenses/by/4.0/). 